\title{
Local Wisdom of Taboos in Karo Language
}

\author{
Jumat Barus ${ }^{1}$, Robert Sibarani ${ }^{2}$, Amrin Saragih $^{3}$, Mulyadi $^{4}$ \\ ${ }_{1,2,3,4}$ Postgraduate Program of Linguistics, Faculty of Cultural Sciences, \\ University of Sumatra Utara, Medan, Indonesia \\ e-mail: auliabs2001@yahoo.com
}

Received: 09 September 2018

Accepted: 24 October 2018

\begin{abstract}
This research aims to explore local wisdom of taboos in Karo language. Taboo is more than prohibitions and avoidance in tradition; it normally arises from social restrictions on individual behaviour that can lead to inconvenience and danger. Taboo was created as a control for community to avoid personal and family conflict. The research was conducted in five sub-districts of Karo, North Sumatra Province, Indonesia. It was carried out by using a qualitative approach with ethnographic methods. The data of local wisdom were obtained from the interview method from nine key informants who mastered and used Karo language and culture well in their daily activities and the writer played a role as the native speaker so that he could directly feel how the culture was implemented in the daily lives of Karo society. It was found that the local wisdoms of taboos in Karo culture were attitude and eagerness to do the best for the community, since taboo rules provide a picture for them about how to express dignified words and behave glorious deeds and how to avoid mentioning disgusting words and behaving impolite manners. The rules become controls for social harmony to be maintained properly. Taboo rules were imposed not to make the society difficult to communicate with each other, but to provide a sense of security and peace for them so that they can live peacefully and harmoniously.
\end{abstract}

Keywords: local wisdom, taboo, kinship relationship.

\section{Introduction}

Every cultured tribe certainly has a cultural product known as taboo, as stated by Danesi (2004: 128), taboo means "holy, untouchable." He further stated that it exists in all cultures and it is generally related to sexuality, the supernatural, excretion, death, and various aspects of social life. He adds that it is generally considered sacred, should not be touched or spoken, since it is considered as a prohibition. While, Allan and Burridge (2006: 27-33) stated that taboos are more than prohibitions and avoidance in tradition. He further said that taboo normally arises from social restrictions on individual behaviour that can lead to inconvenience and danger. Related to those statements, taboo in Karo language generally refers to rebu and kemali. Rebu is a taboo term referring to communication activity that violates cultural rules when it is carried out directly in a kinship between bengkila 'father-inlaw' (husband's father) with permain 'daughter-in-law' (son's wife), turangku 'husband's sister's husband' with turangku 'wife's brother's wife', and mami 'mother-in-law' (wife's mother) with keila 'son-in-law' (daughter's husband). In addition, they are also restricted to 
sit face to face and side by side without intermediaries.

Rebu starts when Karonese get married. After the wedding ceremony there is a ceremony called the mukul marriage rite, held in the groom's parents' house. This is when the bride and groom have dinner from the same plate and the menu has been determined by the groom's parents. Belo pengkapuri (betel leaf which has been filled with areca nut, lime, tobacco and gamber) is given to the bride's rebu and cigarettes are given by the groom to his rebu. He shakes hands with his mother-in-law and his sisters-in-law as they are introduced to their rebu and it is explained that they cannot speak directly to their rebu from that time. The Karonese custom of rebu is considered when mami and kela sit together on a mat, unless there are other people who sit between them, who function as the third person in communication between them (Sembiring, 2013).

Karo language has three intermediary strategies that can be used to avoid such rebu, namely the third person intermediary strategy, metaphor for objects strategy, and the word nina 'said' strategy. In the third person intermediary strategy, the participants of rebu convey their intentions or objectives to others and ask them to convey the intentions to their interlocutors and vice versa. Bengkila conveyed his idea and purpose to others, and asked him to convey it to his permain, and vice versa. When there is no one else around the participants of rebu, they can use metaphor for object strategy. In this strategy, the participants convey their idea to whatever objects are around them, and as if the object could reflect the words conveyed to the interlocutors and vice versa. At such a time, the strategy of the word nina can also be used. When mami talks to her keila, she uses nina keila, and keila talks to her mami using nina mami at the end of his sentence. With these three strategies, people are expected not to violate rebu because they speak via intermediaries or indirectly.

Besides rebu, there are other kinds of taboo, namely bad expression or dirty words which are commonly called kemali. These words or expressions refer to sexual organs and activities and swearing words that are considered to cause discomfort for both speaker and interlocutor. In Karo language, these forms of taboo are classified into context-specific taboo and general taboo. Context-specific taboo includes words which are derived from certain words, which literally do not contain taboo elements (e.g., babah 'mouth'), but they become taboo when (they are) used in swearing (e.g., babahmu ena! 'Your mouth!'); and words which refer to human misfortune aspects (e.g., mehadou 'crazy'). While, general taboo is classified into swearing subgroup (e.g., teli amem 'pussy your mother') and subgroup of dirty words or expression, which include words related to sexual organs and activities (e.g., natu 'dick', entek-entek 'intercourse') and excretion and disposal activities (e.g., tai 'feces', berak 'defecate'). In addition to the two subgroups, it is also considered taboo to mention parents' and senior relatives' names, and to use rough variety to them (Barus, 2018).

The problem of this study is on the fact that taboos which are classified into various groups constitute local wisdoms which are very useful for the community in realizing peace and harmony. Therefore, the research problem is formulated into a question: How is the local wisdom of the Karo language called taboo practiced by the Karonese society?

Concept of cultural meanings and functions is used to explore local wisdoms in terms of taboos. According to Foley (1997: 3), anthropological linguistics views language through the prism of the core anthropological concepts, culture, and, as such, seeks to uncover the meaning behind the use, misuse or non-use, of language, its different forms, registers and styles. Furthermore, he said that anthropological linguistics is an interpretive discipline that explores language in depth to find cultural understandings, and he considers anthropological 
linguistics as a field of science to search for meaning of language and at the same time as a method for understanding culture. Then, in terms of function, Malinowsky (1944/1961: 144) stated that all cultural activities actually function to satisfy a series of instinctual need of human beings related to their lives. Based on the theory, it is concluded that taboos are cultural aspects, either words or activities which are restricted in a certain group of community, which are worth studying so that they can live in harmony and in peace.

\section{Research Method}

This research applied qualitative approach with ethnographic method. The chosen method was considered appropriate because the research was conducted to study language in a cultural framework; that is to study linguistic forms as a fundamental element in human life. The use of such method was also considered fit because the research aimed to explore taboo principles and norms, not only in the lexical meaning of words or phrases, but also in how the process, by whom, and under what conditions the communication is carried out. Duranti (1997: 84) defines that ethnography is a written description of social organization, social activities, material and symbolic sources, and the characteristics of interpretive practices of certain groups of people.

Spradley (1979) said that ethnography is a systematic approach in social science that brings us to all the realities experienced by others and understand them from their perspectives. He further explained that ethnography is an attempt to describe a culture, and it aims to understand how their views and relations towards the societies to achieve their goals (Spradley, 1979: 3-8).

The research was conducted in five sub-districts of Karo, North Sumatra Province, Indonesia, namely: Berastagi district, Kabanjahe district, Tigapanah district, Barus Jahe district, and Simpang Empat district. The data was obtained by interview method. In the implementation, the research was carried out by following twelve steps of developmental research sequence as proposed by Spradley (1979). There were three types of questions proposed and were asked to nine key informants. They were descriptive, structural, and contrast questions. Descriptive questions were to provoke the informants to show the examples of expressions, which were considered taboo in Karo language and to explore the community's understanding about expressions which were considered taboo based on their language, for example, "Please explain what is meant by taboo in Karo language?". The structural question, as "In what kinship are Karo societies not allowed to communicate directly?", served to explore all informants' cultural knowledge about taboo domains existed in the society. While, the contrast questions were served to find out any differences of domain and expressions of taboo. The data were firstly analyzed according to the domain, the taxonomy, and the componential analysis, and then the findings in terms of Karonese local wisdom called taboos were scrutinized to obtain a significant deduction.

\section{Results and Discussion}

\subsection{Meaning of Taboo in Kinship}

Taboo expressions that have a detrimental effect on kinship ethics were found in expressions among bengkila with permain, turangku with turangku, and mami with keila. Taboo of this kind is called rebu, a condition that they cannot speak directly without intermediaries. Rebu starts from a mukul ritual (a traditional rite performed on the night after a wedding ceremony). As in all communities, marriage is a very sacred relationship that is based on a sense of love, so the bond of marriage must be maintained, and both parties 
must do their best to keep the holy bond of marriage and avoid dispute that may lead them to a divorce. One of the ways to maintain the harmony of households in Karo culture is to avoid rebu. Doing rebu means destroying kinship ethics, as it happens in the following short conversation:

(1) Bengkila: Kuja kam e permen?

'Where are you going, permain?'

Permain : Ku kede bengkila, kai kin? (DTK-1, 2017)

'To stall, bengkila, what's the matter?'

The data in (1) shows that bengkila and permain have both violated rebu, they use direct communication, they do not use appropriate strategy in Karo culture.

(2) Turangku (A): Kuja idahndu silihndu ndai, Turangku?

'Where does your brother-in-law go, turangku?'

Turangku (B): I... e la kueteh da, turangku, pak julun ndai ia kuidah, turangku

(DTK-5, 2017)

'I don't know exactly, turangku, I saw him go upstream, turangku'.

In (2), turangku (A) and turangku (B) are both breaking the rebu, they are prohibited to talk one another directly, but they neglect the rule.

(3) Keila : Aku kari naruhken kam, mami!

'I'll take you there, mami!'

Mami : Ya, loka kelana naruhken mamina (DTK-9, 2017)

'No, kela may not do it to his mami .'

In (3), keila himself is breaking the rebu because he offers himself to drive his mami directly, while mami does not break the rebu, and shows her disagreement with keila's attitude and rejects the offer. Expressions in (1), (2), and (3) above are considered to have damaged kinship ethics in Karo culture. In the real ethics, there must be an intermediary among them, they must use intermediary strategies when they want to communicate. Furthermore, conducting direct communication that is not in accordance with the ethics concerned, may lead them to feel more than just in-law's relationships, they may fall in forbidden love, and it can certainly lead to a conflict in their two big families.

Besides, talking without restrictions can sometimes make societies forget to choose the best words they should use. Verbal expressions that are too free often bring about bad effects on a family relationship, especially both parties husband and wife who are from two different families. Therefore, violating the taboo language in this relationship may mean damaging the kinship ethics which should be carefully preserved. It is known that taboo rules have been created and preserved by the ancestors and communities since immemorial era with various challenges, and they felt not easy to go through. Therefore, people who violate the cultural rules, as exemplified earlier, mean to degrade their culture and also insult their ancestors.

Direct speaking in such kinship is also considered violating the ethics of politeness, because speaking in a sacred relationship must obey the appropriate rules, as it is understood that free verbal expression may often bring about negative impacts on their relationship. Based on Karonese ethics, they must use intermediary strategies, so that they can use selected words or expressions in speaking. In this case, people who break the taboos may also be considered impolite. 
In addition to the previous meanings, violating taboo in such relationship may also mean breaking a friendship that has been tied to the marital a relationship. It can happen if the mutual love or hatred arises due to their direct communication. Forbidden love may develop among them and it will surely lead to a conflict, and result in family disharmony.

\subsection{Meaning in Context-Specific and General Taboos}

Verbal expressions in the form of swearing by mentioning several names of bad animals, e.g. pig, dog, buffalo, and monkey, are considered insulting.

(4) Ija banko keretangku ndai, babi? (DTU-12, 2017)

'Where did you put my motorcycle, pig?'

Basically, human beings do not like to be equated with any animals, especially which are bad in the society's view. Speakers who perform such expressions with tendentious voices and intonation are considered to insult their interlocutors. In (4), it is known that the speaker insults his interlocutor, because he equates him with the intended animal, pig.

Furthermore, mentioning the name of wild animals arimo 'tiger', nipe 'snake', gajah 'elephant', which are known for their savagery, and supernatural beings like begu 'ghost/evil spirit' and other frightening supernatural creatures, which are known for their evil deeds to scare and cause people to fall ill, are considered disturbing and challenging the creatures.

(5) Isei kin je rajana? Arimo? (DTI-66, 2017)

'Who is the king here? Tiger?'

Mentioning the name of wild animals and supernatural beings with a tone that seems to challenge them can trigger their anger and damage social harmony because it may cause the counter interlocutor to feel disturbed and offended. It is considered taboo to mention the names of wild animals and the supernatural beings in a discourse, as it may bring about an impact that can endanger the harmony of a community.

Language is flexible because any words expressed may give meaning lexically and connotatively. They can be understood both from its lexical meaning and the meaning of how it is delivered. To show anger, for example, speakers must not always use dirty words. It can also be realized by using words that are lexically meaningless, but in a certain way that means anger, as in (6) below.

Babahmu eina nge ndai ngatakenca! (DTI-2, 2017)

'Your mouth pronounced it!'

In expression (6), the speaker expresses, points to and looks at his interlocutor with a sharp look and a harsh voice. In that way, the use of babah is not just conveying information that the interlocutor was the one who expressed it, but the speaker actually shows his anger.

Further, taboo language also shows the speaker's arrogance. This arrogance can be seen in all categories related to swearing, because in essence swearing contains words that are expressed with louder voice and intonation than they are in normal speech. Moreover, it must usually be expressed in a critical situation.

(7) Takal ninim! (DTI-19, 2017)

'Your grandma's head!'

(8) Dilo nini bulangmu enteh! (DTI-20, 2017)

'Ask your grandpa here!' 
Swearing expressions in (7) and (8) were expressed in critical situation, there was a conflict between the speaker and the interlocutor. They uttered dirty languages with a rude manner and in an impolite way. It certainly implies an emotive expression and the speaker showed himself as an arrogant person.

Taboo can also provide a lot of sadness in others. It may occur when someone has pleasure to mention other's misfortune. For example, mentioning an insane person or mentally ill by mehadou 'crazy', it will make the sufferer's family very sad, as in the following short conversation:

(9) A: Ndigannai mulai mehadou nande kena e?

'When did your mother get crazy?'

B: Atek engko naringe si warasna! (DTI-38, 2017)

'You are like the most sane!'

Basically, all human beings want to be perfect and do not want to have shortcomings both physically and mentally. Experiencing mehadou 'crazy' or a mental disease causes a very sad feeling and condition, that is why, calling the sufferer with such disease in public will cause severe sadness to the family, likewise, for people who suffer from other disgusting diseases such as tabun 'epilepsy', peintang 'blind' and gadam 'leprosy' and palangen 'vaginal pain'. Therefore, Karonese culture prohibits the society from mentioning such expressions as to avoid undignified behaviour which may offend other people's feelings.

Furthermore, it is known that death is a very sad reality for the bereft family, because by the death someone is separated from his family forever. Because of that, the expression of one's death can also increase feelings of sadness to the family who undergo the calamity. Therefore, mentioning the word mate 'die' before the dead person and his family as in (10) is considered taboo; and it may evoke more sadness to the bereft family.

(10) Erdandanken bibi enggo mate ibas wari sisendah, maka kita pulung i jenda... (DTI-11, 2017)

'Our aunt has died this morning, because of that we gather together here....'

Taboo can also trigger a disgraceful action. It can be indicated by expressions related to murder, as in (11) below:

(11) Adi ku rumah ia kari, minter tebak beltekna e! (DTI-17, 2017)

'Later, when he comes home, stab his stomach immediately!'

The verbal expression tebak 'stab' above shows a threat for the safety of others, it is considered taboo in Karo. Therefore, Karo culture prohibits it, and such expression is considered to trigger disgraceful actions.

Taboo expression may also mean abuse at a glorious person. That is reflected in the verbal expression in the swearing group: related to mother (family) and ancestors, mentioning the parents' and senior relatives' name, and using rough variations on the second person pronouns, as in the following expressions:

(12) Takal amem! (DTI-4, 2017)

'Your mother's head!'

(13) O teli ameimu! Kai maka asakko jumaku ahndai? (DTI-18, 2017)

'O your mother's cunt! Why do you harry my field?' 
Basically, Karo society realize that ame 'mother', bapa 'father', nini 'grandma', and nini bulang 'grandpa' are the people who must be glorified and honored. But, in reality some people put them in their swearing expressions. By saying those disgusting words, they can be regarded as having bad attitudes as they dare express such words to people who are supposed to be respected. Such expressions are considered to have harassed them. In Karonese language, it is also considered harassment if someone mentions the names of the elderly that are in higher position both by age and traditional relationships. Moreover, it is also prohibited to talk to them by using rough variation, e.g. ente 'you go', nim 'you said', engko 'you', and certain suffixes that signify second person singular pronouns $-k o,-m u,-m$ 'you'.

Ente lawesken, pa! (DTI-28, 2017)

'You go, dad!'

Uga nim, ka? (DTI-30, 2017)

'What did you say, sister?'

However, in certain urgent cases, in filling in personal data, self introduction purposes and in the occasion of ertutur 'get acquaintance', people may mention their parents' and senior relatives' names.

\subsection{Functions of Taboo}

Taboo is a product of culture. Although the rules are not written they become conventional for the community. Karo people who have good understanding on their culture, realize that they must avoid such languages to realize peace and harmony in the society. However, because of the varied nature and behaviour of the society, it sometimes causes and forces the emergence of taboo language in their activities. Therefore, taboo rules were created as an effort to maintain the peace and harmony in the social lives. More specifically, restrictions on using taboos in the communication have brought about several significant advantages according to the cultural point of views.

Firstly, taboo in kinship among bengkila and permain, turangku and turangku, and mami and keila show the necessity of society to maintain kinship relationships to be harmonious, keep them away from disputes, quarrels, and divorces. Their ancestors believed that, in general, people who have restrictions to speak with each other will rarely evoke conflicts among the society, and conversely people who have their freedom to speak with each other have a greater likelihood of conflict. That kind of conflict will not only affect them, but it has an adverse effect on two large families. Thus, the taboo rules provide a sense of comfort and peace for the society, as dispute and conflict can be prevented and avoided.

Secondly, people as social beings have desire to be respected and loved, and they do not want to be hurt, underestimated, humiliated, reviled, and disturbed. Likewise, other creatures, such as animals and spirits do not want to be disturbed by the people's existence and speech activities. Accordingly, taboo rules give understanding that creatures especially people have these outward innate qualities. Thus, violating the taboo rules means taking others' right.

Furthermore, showing anger, saying harshly, cursing, blaming, and belittling others are forms of vanity. By carrying out such qualities, the community shows that they do not have commendable personalities. Therefore, the presence of taboo rules that limits the society to speak implies the third function of taboo language, that is educating society to be always humble, and they must speak in appropriate words and ways based on their culture. 
The most basic expression of all taboos is that they can cause conflicts or disputes as results of the "loss of face" due to the speech expressed by the participants. Therefore, as a fourth and the very basic function of the taboo rule is to avoid society from being reprehensible. Taboo makes people speak carefully, choose the right words and express it in a good way to avoid hurting others' feeling.

\subsection{Local Wisdom of Taboo in Karonese Language}

From the analysis of meanings and functions of taboo above, it can be concluded that taboo is a specific type of local wisdom. Taboo is an attitude and desire to act and show the best for the society, because taboo rules constitute custom norms of a community to guide the people how they should express feelings, say words and behave and what will happen if the custom is violated.

Furthermore, taboo rules maintain self-respect and create a peaceful and harmonious life as they consist of some strategy how to use language and in what ways to behave. The rules of taboo were deliberately invented to limit the community in carrying out communication activities, so that they could communicate well in accordance with the noble values possessed by the Karo community. Taboo rules were created not to make society difficult to communicate with one another, but to provide a sense of security and peace for the community, for members of society always try to use good expression and maintain their attitudes not to hurt others' feeling.

\section{Conclusion}

From the analysis above, it can be concluded that the local wisdom of taboo language plays very important role in creating harmony and peace of the community. The peculiarities of the taboo found in kinship among bengkila and permain, turangku and turangku, mami and keila are very different from the taboo language existing in some other societies. This taboo has a very interesting distinction to be explored. In this type of taboo, rebu is not only specifically to avoid speakers' and interlocutors' discomfort in speaking, but also to maintain the integrity of family that had been tied with a sacred marriage relationship. In general, people realize that taboo controls the rights and obligations of the community members in the communication to create a comfortable and peaceful atmosphere in the society.

\section{References}

Allan, K., \& Burridge, K. (2006). Forbidden Words: Taboo and the Cencoring of Language. New York: Cambridge University Press.

Barus, J., Sibarani, R., Saragih, Amrin., \& Mulyadi. (2018). Linguistic Taboos in Karonese Culture. Proceeding of The 1st Annual International Conference on Language and Literature (AICLL), 1(1), 348-356. Medan: Fakultas Sastra UISU. DOI: 10.18502/kss.v3i4.1952.

Danesi, M. (2004). A Basic Course in Anthropological Linguistics. Toronto: Canadian Scholars' Press Inc.

Duranti, A. (1997). Linguistic Anthropology. New York: Cambridge University Press.

Foley, W. A. (1997). Anthropological Linguistics: An Introduction. Oxford: Blackwell.

Malinowski, B. (1944/1961). A Scientific Theory of Culture and Other Essays. New York: Oxford University Press. 
Sembiring, M. (2013). Translating Rebu in Karonese Society into English. IOSR Journal of Humanities and Social Science (IOSR-JHSS), 17.(1), 30-36. Retrived from http://www.iosrjournals.org.

Spradley, J.P. (1979). The Ethnographic Interview. USA: Hartcourt Brace Jovanovich College Publishers. 